Special issue of the 2nd International Conference on Computational and Experimental Science and Engineering (ICCESEN 2015)

\title{
Calculation of the $(\mathbf{p}, \mathbf{n})$ Reaction Cross Section of Radionuclides Used for PET Applications
}

\author{
F. KilinÇ ${ }^{a}$, N. KARPUZ ${ }^{b}$ AND B. ÇETIN ${ }^{a, *}$ \\ ${ }^{a}$ Amasya University, Sciences \& Arts Faculty, Amasya, Turkey \\ ${ }^{b}$ Amasya University, Sabuncuoğlu Şerefeddin Health Services Vocational School, Amasya, Turkey \\ Positron emission tomography is an imaging method which plays an important role in the diagnosis and moni- \\ toring of cancer cells using radioactive substances. In this study (p,n) reaction cross sections of some radionuclides \\ (Cu-61, Ga-66, Br-76) were calculated using Talys 1.6 nuclear simulation code. The calculated cross-sections were \\ compared with experimental values taken from EXFOR.
}

DOI: 10.12693/APhysPolA.130.318

PACS/topics: 13.85.Lg, 13.87.Ce

\section{Introduction}

Radioisotopes release their energy by emitting gamma rays, which can be detected with modern equipment. There are many radionuclide substances which are suitable for use in diagnostics. A small part of them is used as the radiation source for therapeutic purposes.

Radioisotopes used in medical field are produced in accelerators or using nuclear reactors. In the production of artificial radioisotopes, the high energy particles of the incoming beam collide with the nuclei. Cross section of the reaction, is used to characterize the reduction of the incoming beam [1]. Cross-section plays an important role in the production of radioisotopes.

In recent years positron emission tomography (PET) imaging technique is widely used for diagnostic purposes in nuclear medicine in our country. This imaging technique is used for the early diagnosis of cancer diseases and is used in the heart-related studies. ${ }^{18} \mathrm{~F},{ }^{11} \mathrm{C},{ }^{13} \mathrm{~N},{ }^{15} \mathrm{O}$ positron-emitting radionuclides are produced for PET applications [2]. Nowadays however, other short-lived radionuclides such as ${ }^{61} \mathrm{Cu},{ }^{66} \mathrm{Ga},{ }^{76} \mathrm{Br}$ are under study. ${ }^{61} \mathrm{Cu}$ radioisotope is used in the PET imaging. ${ }^{66} \mathrm{Ga}$ is used in the PET imaging of biological processes in target tissues. ${ }^{76} \mathrm{Br}$ is used in DNA studies, in the studies of the nerves of the heart and in digital imaging.

After a radioactive decay process of the radionuclide, the resulting nucleus becomes stable. Meanwhile, a proton is transformed into two new particles, a positively charged positron and a neutron. Positron is thrown out from the nucleus. The advancing positron, after a short distance, collides with electrons of another atom. As a result, the energy of the destroyed mass is transformed into the energy of two gamma quanta of $511 \mathrm{keV}$, which propagate in opposite directions.

Radiation therapy is a form of cancer treatment that uses radiation to destroy malignant cells. For this

\footnotetext{
*corresponding author; e-mail: betulcetin3205@gmail.com
}

purpose, ${ }^{137} \mathrm{Cs}$ is used in radiotherapy due to its appropriate physical half-live. Itx is produced during the fission the ${ }^{235} \mathrm{U}$ core. Cross sections of the $(\mathrm{n}, \mathrm{f})$ reaction have been calculated for ${ }^{235} \mathrm{U}$ in [3]. At the same time, some isotopes such as iodine are vital, especially in medical science and thus production of these isotopes is important. Cross sections of the ${ }^{125} \mathrm{Te}(\mathrm{p}, \mathrm{xn})$ reaction, in which iodine can be produced, were calculated for the $5.5-100.5 \mathrm{MeV}$ energy range using Talys code and compared with results obtained by ALICE/ASH code in [4].

\section{Software and methods}

In this study, cross-section $\sigma$ values for the ${ }^{61} \mathrm{Ni}(\mathrm{p}, \mathrm{n})$ ${ }^{61} \mathrm{Cu},{ }^{66} \mathrm{Zn}(\mathrm{p}, \mathrm{n}){ }^{66} \mathrm{Ga}$ and ${ }^{76} \mathrm{Se}(\mathrm{p}, \mathrm{n}){ }^{76} \mathrm{Br}$ reactions were calculated using Talys 1.6 [5] nuclear reaction simulation code.

Talys is a nuclear reaction simulation code for the analysis and prediction of nuclear reactions. Talys 1.6 program examines the interaction of protons, neutrons, deuteron, triton, gamma, alpha and $3 \mathrm{He}$ particles in the energy range of $1 \mathrm{keV}-1 \mathrm{GeV}$ with nuclei with mass of 12 or more. It is written in FORTRAN programming language and runs on Linux operation system.

\section{Results and discussions}

The calculated ${ }^{61} \mathrm{Ni}(\mathrm{p}, \mathrm{n}){ }^{61} \mathrm{Cu},{ }^{66} \mathrm{Zn}(\mathrm{p}, \mathrm{n}){ }^{66} \mathrm{Ga}$ and ${ }^{76} \mathrm{Se}(\mathrm{p}, \mathrm{n}){ }^{76} \mathrm{Br}$ production reaction cross sections are shown in Figs. 1-3. The obtained results have been compared with the experimental data existing in the EXFOR [6] database.

\section{Conclusions}

In this work production cross section values for the reactions of ${ }^{61} \mathrm{Ni}(\mathrm{p}, \mathrm{n}){ }^{61} \mathrm{Cu},{ }^{66} \mathrm{Zn}(\mathrm{p}, \mathrm{n}){ }^{66} \mathrm{Ga}$ and ${ }^{76} \mathrm{Se}$ $(\mathrm{p}, \mathrm{n}){ }^{76} \mathrm{Br}$ were calculated in the energy range between 1 and $100 \mathrm{MeV}$. Our results are in fair agreement with experimental data available in the literature. The maximum cross section values are $427.307 \mathrm{mb}$ at $9.5 \mathrm{MeV}$ for 




Fig. 1. The calculated cross sections of ${ }^{61} \mathrm{Ni}(\mathrm{p}, \mathrm{n}){ }^{61} \mathrm{Cu}$ reaction and comparison with experimental results.

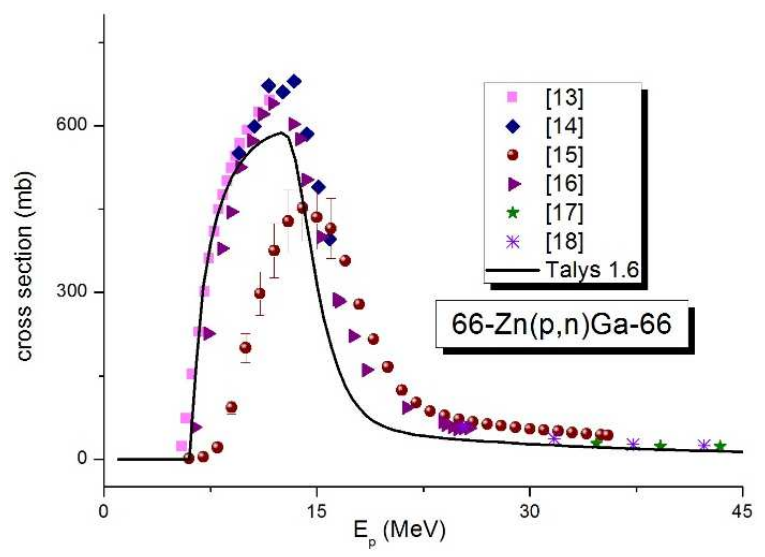

Fig. 2. The calculated cross sections of ${ }^{66} \mathrm{Zn}(\mathrm{p}, \mathrm{n}){ }^{66} \mathrm{Ga}$ reaction and comparison with experimental results.

${ }^{61} \mathrm{Cu}$ production, $587.871 \mathrm{mb}$ at $12.5 \mathrm{MeV}$ for ${ }^{66} \mathrm{Ga}$ and $767.445 \mathrm{mb}$ at $13 \mathrm{MeV}$ for ${ }^{76} \mathrm{Br}$ production. The most appropriate production range for ${ }^{61} \mathrm{Ni}(\mathrm{p}, \mathrm{n}){ }^{61} \mathrm{Cu}$ nuclear reaction is $7-11 \mathrm{MeV}$. The most appropriate production range for ${ }^{66} \mathrm{Zn}(\mathrm{p}, \mathrm{n}){ }^{66} \mathrm{Ga}$ nuclear reaction is $10-13 \mathrm{MeV}$.
The most appropriate production range for ${ }^{76} \mathrm{Se}(\mathrm{p}, \mathrm{n})$

${ }^{76} \mathrm{Br}$ nuclear reaction is $11-14 \mathrm{MeV}$.

Cross sections of reactions used in production of ${ }^{61} \mathrm{Cu}$, ${ }^{66} \mathrm{Ga}$ and ${ }^{76} \mathrm{Br}$ isotopes were calculated. The calculated results were compared with the results of experimental data from the literature. It is seen from the figures that theoretical results calculated using the Talys 1.6 program are compatible with the experimental data from literature.

\section{References}

[1] A.P. Arya, Çekirdek Fiziğinin Esasları, Aktif Yayınevi, Erzurum 1999 (in Turkish).

[2] D. Yıldız, M.Sc. Thesis, Gazi Üniversitesi, Fen Bilimleri Enstitüsü, 2010.

[3] N. Karpuz, M.C. Boz, B. Mavi, F. Öner, İ. Akkurt, Acta Phys. Pol. A 128, B-363 (2015).

[4] N. Karpuz, İ. Akkurt, B. Mavi, Ann. Nucl. Energy 60, 341 (2013).

[5] A. Koning, S. Hilaire, S. Goriely, TALYS-1.6 A Nuclear Reaction Program, User Manual, NRG, The Netherlands 2013.

[6] EXFOR/CSISRS, Experimental Nuclear Reaction Data File, Brookhaven National Laboratory, National Nuclear Data Center, 2009.

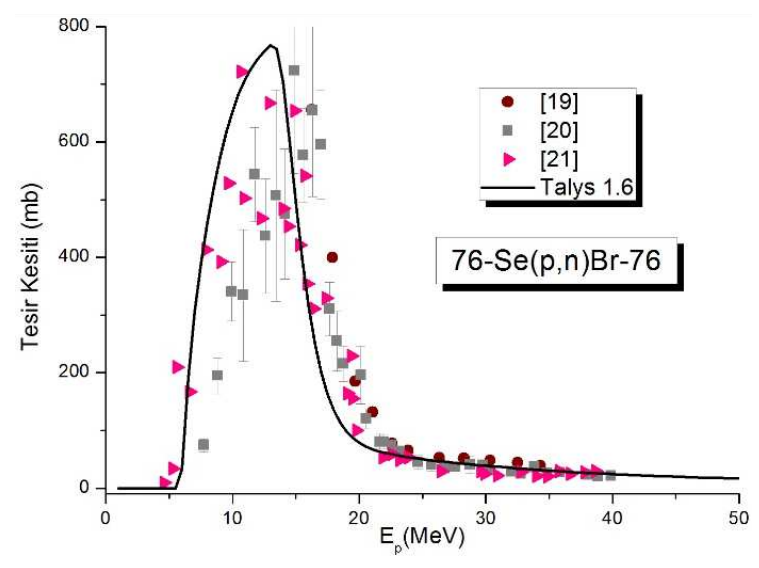

Fig. 3. The calculated cross sections of ${ }^{76} \mathrm{Se}(\mathrm{p}, \mathrm{n}){ }^{76} \mathrm{Br}$ reaction and comparison with experimental results. 